\title{
An Empirical Study on Financing Preference of Listed Military Industry Enterprises in China
}

\author{
Li-Na Chen*, Ying Lei \\ 31008 Unit, PLA, 100091, BeiJing, China
}

\begin{abstract}
Financing is an important part in the development of military enterprises, and it plays an important role in the development of military enterprises. By using empirical analysis method, 22 companies are selected as samples. The factor analysis and multivariate linear regression method are used to quantitatively analyze the internal factors of the company. These internal factors affect the financing preference of listed companies in China's military industry. Then conclusions are drawn and relevant suggestions are put forward.
\end{abstract}

\section{INTRODUCTION}

The defense industry as an important industry of China's economic development and a pillar industry to safeguard national security, especially China is facing the external environment of the general peace and local wars in the international situation, and its role is increasingly prominent in the development of the national economy. However, with the development of China's market economy, the development of military industry is lagging behind the development of other industries. It is mainly reflected in the low profit margin, the single source of funds and the lack of funds. There are many reasons for the above problems, but the financing problem is more prominent. And financing, as the key link of the enterprise development, plays an important role in the development of the enterprise. However, the financing mode of military industrial enterprises in China is still dominated by traditional bank loans. To some extent, this limits the fact that enterprises can not make extensive use of capital market to promote the development of enterprises, resulting in a series of problems, such as high cost of financing and low efficiency of fund utilization. Therefore, it is necessary for us to study the financing problems of our military enterprises systematically, so as to improve the financing efficiency and broaden the financing channels for military enterprises.

Some scholars have studied the above problems. For example, Rui Ma used the data of 2006-2008 of China's military industrial enterprises to make an empirical study on the relationship between the military enterprises and the government and the banks. Shusheng Li used comparative method to study the financing ways of Chinese military enterprises and the US military industry enterprises, and put forward suggestions for the problems of the financing of our military enterprises. Jianchang Liu and other problems in the financing of military enterprises in China are analyzed, and measures to improve the problems are put forward. $\mathrm{Xu}$ Zhang and other methods used fuzzy evaluation method to evaluate the financing mode of China's military industry. According to the conclusion of evaluation, we put forward some suggestions for the financing problems of China's military industry. By analyzing the current situation of investment and financing in China's military industry, Shuxia Ren put forward the problems in the financing of China's military industry, and put forward corresponding strategies according to the actual situation.

The above scholars have analyzed the problems in our military industry financing from different levels, and put forward the corresponding measures and suggestions. But most of them are studied from a statistical or descriptive point of view or one aspect of the financing. This paper will study the problems of military industry financing in China from the perspective of empirical analysis, and put forward some relevant suggestions.

\section{VARIABLE SELECTION}

(1) Dependent Variable

In the selection of the dependent variables, this paper chooses the average shareholder equity ratio of the listed companies in the military industry for 2012-2015 years, which can be more intuitively responsive to the equity financing preference.

(2) Independent Variable

At present, most scholars consider all the listed companies when they choose relevant indicators, while the analysis for a specific industry is relatively few, especially for the military industry, the empirical research of financing preference is basically blank. This paper combines the characteristics of China's military industry and the availability of relevant data.9 factors, such as profitability, debt paying ability, growth ability, operating capacity, dividend payment level, tax shield

\footnotetext{
"Corresponding author: Li-Na Chen: 9309806@qq.com
} 
value, enterprise scale, CVOA and HERF, are selected as the object of empirical analysis of the influencing factors of financing preference of military industry listed companies. 23 indicators, such as earnings per share, Roe, are used as concrete indicators to carry out empirical research.

Table 1. Empirical Analysis Index Selection of Listed Companies in Military Industry.

\begin{tabular}{|c|c|c|}
\hline $\begin{array}{c}\text { Index } \\
\text { classification }\end{array}$ & Index name & Index definition \\
\hline \multirow{4}{*}{ Profitability } & Earnings per share & Net margin/ Total equity \\
\hline & Roe & Net margin / Net assets \\
\hline & Return on assets & $\begin{array}{c}\text { Net margin / Average asset } \\
\text { total }\end{array}$ \\
\hline & Net profit margin & Net margin/ Operating income \\
\hline \multirow{3}{*}{$\begin{array}{l}\text { Debt paying } \\
\text { ability }\end{array}$} & Current ratio & $\begin{array}{c}\text { Circulating assets / Cash } \\
\text { liabilities }\end{array}$ \\
\hline & Quick ratio & Quick assets / Cash liabilities \\
\hline & $\begin{array}{c}\text { Interest coverage } \\
\text { ratio }\end{array}$ & $\begin{array}{l}\text { (Total profit + Capital } \\
\text { charges) / Interest cost }\end{array}$ \\
\hline \multirow{4}{*}{ Growth ability } & EPSG & $\begin{array}{c}\text { (Final - Beginning) / } \\
\text { Beginning }\end{array}$ \\
\hline & $\begin{array}{c}\text { Increase rate of } \\
\text { business revenue }\end{array}$ & $\begin{array}{c}\text { (Final - Beginning) / } \\
\text { Beginning }\end{array}$ \\
\hline & Net profit growth rate & $\begin{array}{c}\text { (Final - Beginning) } / \\
\text { Beginning }\end{array}$ \\
\hline & $\begin{array}{l}\text { Total Assets Growth } \\
\text { Rate }\end{array}$ & $\begin{array}{c}\text { (Final - Beginning) / } \\
\text { Beginning }\end{array}$ \\
\hline \multirow{4}{*}{$\begin{array}{l}\text { operating } \\
\text { capacity }\end{array}$} & $\begin{array}{l}\text { inventory turnover } \\
\text { ratio } \\
\end{array}$ & $\begin{array}{c}\text { Sales income/average } \\
\text { inventory }\end{array}$ \\
\hline & $\begin{array}{l}\text { average accounts } \\
\text { receivable turnover } \\
\text { ratio }\end{array}$ & $\begin{array}{l}\text { Sales income/Average } \\
\text { accounts receivable }\end{array}$ \\
\hline & Equity Turnover & $\begin{array}{l}\text { Sales income / Average } \\
\text { shareholders' equity }\end{array}$ \\
\hline & $\begin{array}{l}\text { Turnover of total } \\
\text { capital }\end{array}$ & $\begin{array}{c}\text { Sales income / Average total } \\
\text { assets }\end{array}$ \\
\hline \multirow[b]{2}{*}{$\begin{array}{c}\text { Dividend } \\
\text { payment level }\end{array}$} & Dividend per share & Total dividend / Total stock \\
\hline & Dividend payout ratio & $\begin{array}{c}\text { Dividend per share / Earnings } \\
\text { per share }\end{array}$ \\
\hline $\begin{array}{l}\text { Tax shield } \\
\text { value }\end{array}$ & Effective tax rates & Income tax / Total profit \\
\hline \multirow{2}{*}{$\begin{array}{l}\text { Enterprise } \\
\text { scale }\end{array}$} & $\mathrm{LN}$ total assets & $\begin{array}{l}\text { The logarithm of the total } \\
\text { assets }\end{array}$ \\
\hline & $\mathrm{LN}$ income & $\begin{array}{c}\text { The logarithm of business } \\
\text { income }\end{array}$ \\
\hline $\begin{array}{c}\text { Collateral } \\
\text { Value of } \\
\text { Assets }\end{array}$ & Hypothecary value & $\begin{array}{c}\text { (Inventory }+ \text { Fixed assets }) / \\
\text { Total assets }\end{array}$ \\
\hline \multirow[b]{2}{*}{ HERF } & $\begin{array}{l}\text { The proportion of the } \\
\text { top five shareholders }\end{array}$ & $\begin{array}{c}\text { Total share of the top five } \\
\text { shareholders / Total equity }\end{array}$ \\
\hline & $\begin{array}{c}\text { First largest } \\
\text { shareholder ratio }\end{array}$ & $\begin{array}{c}\text { Number of first largest } \\
\text { shareholder / Total share } \\
\text { capital } \\
\end{array}$ \\
\hline \multirow{2}{*}{$\begin{array}{l}\text { Capital } \\
\text { composition }\end{array}$} & Asset-liability ratio & Gross liabilities/ Total assets \\
\hline & Equity Ratio & $\begin{array}{l}\text { Shareholders' equity / Total } \\
\text { assets }\end{array}$ \\
\hline
\end{tabular}

\section{EMPIRICAL ANALYSIS}

\section{(1) Data and Sample Selection}

The sample size, 2013, 2014, 2015, and three years' data of the listed military companies are analyzed in this paper to analyze the main factors that affect the capital structure of military listed companies. In order to ensure the effectiveness of the sample data, the enterprises that issue A shares listed on the main board market are selected. In order to ensure the true reliability of the data, the sample of ST military listed companies is eliminated, and 22 effective samples are finally obtained.

The data used in this paper are derived from the Wind financial advisory terminal database. The full text data processing and analysis mainly uses the Excel2007 and SPSS20.0 statistical analysis software.

(2) Factor Construction

The eigenvalue and variance contribution rate of the extracted principal component factors are shown in Table 2. It can be seen from the table that the eigenvalue of the first factor is 6.668 , accounting for $29.484 \%$ of the variance; The eigenvalues of the second factors are 3.523 , accounting for $15.529 \%$ of the variance; The cumulative contribution rate of the variance of the first 7 factors is $83.62 \%$, It can be seen that the variance explained by the other 16 factors is only $16.38 \%$, which indicates that the 7 factors extracted in this paper well preserve the information of the original variable, so the extracted common factor has good representativeness.

Table 2. Factor eigenvalue and cumulative variance contribution rate.

\begin{tabular}{|c|c|c|c|c|c|c|}
\hline \multirow{2}{*}{$\begin{array}{l}\text { Ingre } \\
\text { dients }\end{array}$} & \multicolumn{3}{|c|}{ Initial Eigenvalues } & \multicolumn{3}{c|}{$\begin{array}{c}\text { Extracting square sum and } \\
\text { loading }\end{array}$} \\
\cline { 2 - 7 } & Total & $\begin{array}{c}\text { Variance } \\
\text { \% }\end{array}$ & $\begin{array}{c}\text { accumulate } \\
\text { \% }\end{array}$ & Total & $\begin{array}{c}\text { Variance } \\
\text { \% }\end{array}$ & $\begin{array}{c}\text { accumula } \\
\text { te \% }\end{array}$ \\
\hline 1 & 6.668 & 29.484 & 29.484 & 6.668 & 29.484 & 29.484 \\
\hline 2 & 3.523 & 15.529 & 45.013 & 3.523 & 15.529 & 45.013 \\
\hline 3 & 2.699 & 11.478 & 56.491 & 2.699 & 11.478 & 56.491 \\
\hline 4 & 1.979 & 8.624 & 65.115 & 1.979 & 8.624 & 65.115 \\
\hline 5 & 1.680 & 7.743 & 72.858 & 1.680 & 7.743 & 72.858 \\
\hline 6 & 1.211 & 5.569 & 78.427 & 1.211 & 5.569 & 78.427 \\
\hline 7 & 1.136 & 5.194 & 83.621 & 1.136 & 5.194 & 83.621 \\
\hline 8 & 0.888 & 3.942 & 87.563 & & & \\
\hline 9 & 0.794 & 3.255 & 90.818 & & & \\
\hline 10 & 0.535 & 2.474 & 93.292 & & & \\
\hline 11 & 0.460 & 2.023 & 95.315 & & & \\
\hline 12 & 0.331 & 1.853 & 97.168 & & & \\
\hline 13 & 0.235 & 1.052 & 98.22 & & & \\
\hline 14 & 0.151 & 0.671 & 98.891 & & & \\
\hline 15 & 0.112 & 0.465 & 99.356 & & & \\
\hline 16 & 0.065 & 0.299 & 99.655 & & & \\
\hline 17 & 0.040 & 0.181 & 99.836 & & & \\
\hline 18 & 0.026 & 0.113 & 99.949 & & & \\
\hline 19 & 0.009 & 0.048 & 99.997 & & & \\
\hline 20 & 0.001 & 0.002 & 99.999 & & & \\
\hline 21 & 0.000 & 0.001 & 100 & & & \\
\hline 22 & $3.68 \mathrm{E}-$ & & & & & \\
\hline & 17 & $1.63 \mathrm{E}-16$ & 100 & & & \\
\hline & $-6 \mathrm{E}-16$ & $-2.64 \mathrm{E}-15$ & 100 & & & \\
\hline
\end{tabular}

$F_{i}(i=1,2 \ldots 7)$ is defined as a common factor. Through the observation of the factor load matrix, it is found that: $F_{1}$ has an absolute value of load on earnings per share, Roe, return on assets and net profit margin. So we think the main reflection of the company's profitability, what we call "profitability" factor. The $F_{2} \sim F_{7}$ can be found in the current ratio and quick ratio, EPSG and net profit growth rate, the growth ability of the company, average accounts receivable turnover ratio and inventory turnover ratio, The proportion of the top five shareholders and First largest shareholder ratio, 
hypothecary value, dividend payout ratio has absolute value greater load coefficient.

$F_{2} \sim F_{7}$ are called "debt paying ability" factor, "Growth ability" factor, "operating capability" factor, "equity structure" factor, "Collateral Value of Assets" factor and "Dividend payment level" factor respectively.

(3) Model Building

The shareholder equity ratio $(Y)$ is the ratio of the owner's equity to the total assets. The average shareholder equity ratio of Listed Companies in the military industry for nearly three years can be more intuitively responsive to equity financing preference. In this paper, the principal component analysis method is selected to extract 7 principal component factors as independent variables. Because of the factor analysis, the correlation between variables and multiple collinearity are eliminated, and the seven principal component factors are calculated by the factor score matrix.

$$
Y=b_{0}+\sum_{i=1}^{7} b_{i} F_{i}+\varepsilon
$$

$b_{0}$ is a constant term, $\varepsilon$ is a random variable

(4) Test Results and Analysis

Table 3. Test Results

\begin{tabular}{|c|c|c|c|c|c|c|}
\hline \multicolumn{2}{|c|}{ Model } & $\begin{array}{c}\text { Sum of } \\
\text { squares }\end{array}$ & df & $\begin{array}{c}\text { Mean } \\
\text { square }\end{array}$ & F & Sig. \\
\hline \multirow{2}{*}{1} & Regression & 15.148 & 7 & 2.361 & 8.940 & $.001^{\text {a }}$ \\
\cline { 2 - 7 } & $\begin{array}{c}\text { Residual } \\
\text { error }\end{array}$ & 4.661 & 14 & 0.348 & & \\
\cline { 2 - 7 } & Total & 21.000 & 21 & & & \\
\hline
\end{tabular}

a. Predictive Variable: (Constant), Common factor 7, Common factor2, Common factor5, Common factor6, Common factor3, Common factor1, Common factor4

b. Dependent variable: Equity Ratio

Table 4. Model Coefficient Table

\begin{tabular}{|c|c|c|c|c|c|c|}
\hline \multirow{2}{*}{ Model } & \multicolumn{2}{|c|}{$\begin{array}{c}\text { Unstandardized } \\
\text { Coefficients }\end{array}$} & $\begin{array}{c}\text { Standardized } \\
\text { beta coefficients }\end{array}$ & \multirow{2}{*}{ t } & \multirow{2}{*}{ Sig. } \\
\cline { 2 - 5 } & B & $\begin{array}{c}\text { Standard } \\
\text { error }\end{array}$ & Trial version & & \\
\hline \multirow{2}{*}{1} & (constant) & $-1.532 \mathrm{E}-6$ & .124 & & .000 & 1.000 \\
\hline $\begin{array}{c}\text { common } \\
\text { factor } 1\end{array}$ & .240 & .127 & 0.248 & 1.950 & 0.068 \\
\hline $\begin{array}{c}\text { common } \\
\text { factor2 }\end{array}$ & -.766 & .127 & -0.768 & -6.043 & 0 \\
\hline $\begin{array}{c}\text { common } \\
\text { factor3 }\end{array}$ & -.201 & .127 & 0.198 & 1.559 & 0.136 \\
\hline $\begin{array}{c}\text { common } \\
\text { factor4 }\end{array}$ & -.092 & .127 & -0.090 & -0.709 & 0.481 \\
\hline $\begin{array}{c}\text { common } \\
\text { factor5 }\end{array}$ & .142 & .127 & 0.139 & 1.090 & 0.286 \\
\hline $\begin{array}{c}\text { common } \\
\text { factor6 }\end{array}$ & -.213 & .127 & 0.201 & 1.584 & 0.131 \\
\hline $\begin{array}{c}\text { common } \\
\text { factor7 }\end{array}$ & $-2.065 \mathrm{E}-5$ & .127 & .000 & .000 & 1.000 \\
\hline
\end{tabular}

a. Dependent Variable: Equity Ratio

The results of the multivariate linear regression model are as follows:

$$
\begin{aligned}
& Y=-1.558 E^{-6}+0.240 F_{1}-0.776 F_{2}-0.201 F_{3} \\
& -0.092 F_{4}+0.142 F_{5}-0.213 F_{6}-2.065 E^{-5} F_{7}+\varepsilon
\end{aligned}
$$

Through the empirical analysis of the financing preference of the listed companies in the military industry, we can see that: The profitability of an enterprise is positively related to the equity ratio, with a coefficient of 0.240 . Because the stronger the profitability of an enterprise, the more profits can be retained for the redevelopment of the enterprise. The short term solvency of an enterprise is anti-related to the equity ratio, and its coefficient is -0.766 . The stronger the solvency of the enterprise is, the stronger the liquidity is, the easier it is for the business to merge from the bank loan or the issue bond to the debt fund, and the relative level of debt increases, resulting in a relative reduction of the stockholders' equity ratio. The growth ability of the enterprise is positively related to the equity ratio, and its coefficient is -0.201 . The better the growth ability of enterprises is, the better prospects for enterprises to be compared with other enterprises or the whole market. Therefore, enterprises are reluctant to issue shares to the capital market, and on the other hand, most Chinese military enterprises rely on bank loans for financing. The operating capacity of an enterprise is antirelated to the equity ratio, and its coefficient is -0.091 . In theory, The better the operating capacity of an enterprise shows, the better the enterprise's capacity for capital turnover. The smaller the demand for debt, the relatively low level of debt and the relative increase in the equity ratio. That is, the operating capacity is proportional to the equity ratio. But the empirical results of this paper are opposite. It shows that China's military enterprises are not willing to finance the market. The ratio of equity structure and equity ratio has a positive correlation to a certain extent, with a coefficient of 0.140 . The more centralized the ownership of the enterprises, the greater the influence of the shareholders to the financing preference of the listed companies. To make the financing needs of the listed companies more satisfied through equity financing. The Collateral Value of Assets and the equity ratio are in a positive correlation to a certain extent, with a coefficient of -0.203 . Most of our military listed companies belong to large and mediumsized state-owned enterprises, representing the relative position and the right to speak in the military industry. In theory, the larger the scale, the greater the proportion of tangible assets (fixed assets and inventory). The greater the asset guarantee value is, the higher the credit of the enterprise is, the easier it is to get the debt financing such as bank loans, and the ratio of stockholders' equity is also lower. There is a positive correlation between the dividend payment level and the equity ratio to a certain extent, the coefficient of which is $-2.065 \mathrm{E}-5$. When the profitability of a company is constant, the higher the dividend payout level, the less the retained earnings and the lower the stockholder's equity ratio. This shows that the listed companies of the military industry prefer bank loans.

\section{CONCLUSIONS}


Through the analysis of the above results, we find that profitability, short-term debt paying ability, growth ability, equity structure and Collateral Value of Assets have different effects on the financing preference of China's military industry listed companies. Therefore, for military industry listed companies, when financing is carried out, we should combine the unique characteristics of military enterprises and adhere to the basic principles of total financing revenue and total cost of financing to determine the optimal capital structure of enterprises. In terms of specific measures, we should consider the main factors that influence the financing preference of military industry listed companies, so as to consider improving the structure of related factors, so as to achieve the best corporate capital structure, so that the value of enterprises can be maximized.

(1) Optimizing the Equity Structure of Enterprises

At present, the state-owned shares of China's military listed companies account for a large proportion. Therefore, the decision-making level should consider reducing the state-owned shares and encouraging the transfering of the legal person shareholders, so that the legal investors can be more concerned about the longterm interests of the company and the development of the company's business. Moreover, whether state-owned shares or corporate shares are common stocks, they should gradually circulate state-owned shares and public shares, which is conducive to the optimal allocation of resources.

(2) The Government Promotes Financial Innovation The government should actively promote the financial market, financial product innovation, the establishment of a multi-level and diversified capital market system, to diversify the financing instruments and financing mode, promote the development of private equity and bond market, reducing the financing cost of listed companies, to meet the needs of listed companies and investor diversification, improve the efficiency of resource allocation.

\section{REFERENCES}

1. Ma Rui, Fu construction. An Empirical Study on the convenience of debt financing for listed military enterprises [J]. Heilongjiang foreign trade and economic economic and trade, 2010,(06):117-119.

2. Li Shusheng. Research on stock financing preference of listed military enterprises in China [D]. Henan University, 2011.

3. Liu Jianchang, Shi Xiu, Zhang Xiaoqian, Xie Wen Qiang. Research on the financing model of military industrial enterprises in China $[\mathrm{J}]$. Industrial Economic Forum,2015,(04):118-126.

4. Zhang $\mathrm{Xu}, \mathrm{Liu}$ Jianchang, Hou Guangxi. Comprehensive evaluation of multiple financing methods in military enterprises -- Based on the [J]. Technology and economy of fuzzy network analysis, 2013, (11):81-87+118.

5. Ren Shuxia. Research on the investment and financing model of military industry enterprises in China based on the development of military and civilian integration, [J].Modern economic information,2016,(11):300. 